\title{
$\bar{A} \mid$\begin{tabular}{l|l} 
SCHOOL OF LAW \\
Ta
\end{tabular}

Volume 7

Number 3 Oil \& Gas Survey

Article 6

5-12-2021

\section{Michigan Oil and Gas Update}

William A. Horn

whorn@mikameyers.com

Joshua D. Beard

JBeard@mikameyers.com

Follow this and additional works at: https://scholarship.law.tamu.edu/journal-of-property-law

Part of the Oil, Gas, and Mineral Law Commons, and the Property Law and Real Estate Commons

\section{Recommended Citation}

William A. Horn \& Joshua D. Beard, Michigan Oil and Gas Update, 7 Tex. A\&M J. Prop. L. 378 (2021). Available at: https://doi.org/10.37419/JPL.V7.I3.6

This Student Article is brought to you for free and open access by Texas A\&M Law Scholarship. It has been accepted for inclusion in Texas A\&M Journal of Property Law by an authorized editor of Texas A\&M Law Scholarship. For more information, please contact aretteen@law.tamu.edu. 


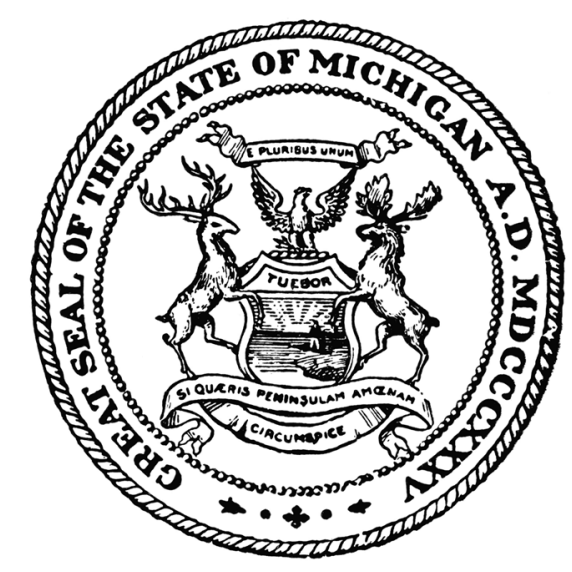

Michigan OIL ANd Gas Update

\section{William A. Horn and Joshua D. Beard ${ }^{\dagger}$}

On March 23, 2020, the Michigan Court of Claims issued its opinion in Mannes v. Michigan Dep't of Treasury. ${ }^{1}$ This case considered the meaning of the phrase "expenses of producing oil and gas" as such expenses relate to "taxable income" under the Michigan Income Tax Act of $1967 .^{2}$

The Michigan Income Tax Act defines "taxable income" as "adjusted gross income as defined in the Internal Revenue Code" less

DOI: https://doi.org/10.37419/JPL.V7.I3.6

${ }^{\dagger}$ Mr. Horn is a Member at Mika Meyers PLC, Grand Rapids, Michigan. J.D., 1981 cum laude, University of Wisconsin Law School. Mr. Horn practices in the area of natural resources and environmental law, representing oil and gas exploration and production companies in regulatory, administrative and litigation matters. Mr. Horn served as an adjunct professor at Western Michigan University Cooley Law School, where he taught environmental and natural resources law. Mr. Beard is a Member at Mika Meyers PLC, Grand Rapids, Michigan. J.D., 2009, University of Michigan Law School. Mr. Beard practices in the area of environmental, energy and natural resources law, with a particular emphasis on oil and gas exploration and production matters, including acquisitions and divestments of oil and gas properties, complex title issues, and regulatory matters.

1. Mannes v. Mich. Dep’t of Treasury, No. 18-000235-MT, 2020 WL 3891898 at*1 (Mich. Ct. Cl. Mar. 23, 2020).

2. Id. at *1-2. 
certain specified adjustments. ${ }^{3}$ As defined in the Internal Revenue Code, adjusted gross income includes gross income from the production of oil and gas. In calculating the federal adjusted gross income, taxpayers may deduct expenses of carrying on any trade or business from gross income. ${ }^{4}$

Michigan has a separate tax statute applicable to the taxation of income from the production of oil and gas. The Michigan Severance Tax $\mathrm{Act}^{5}$ levies a tax on each producer engaged in the business of severing oil or gas from Michigan soil. This severance tax is levied on the gross market value of the oil or gas at the time of severance and is "in lieu of all other taxes, state or local, upon the oil or gas, the property rights attached thereto or inherent therein, or the values created thereby." $"$ This provision has been interpreted as exempting oil and gas income from other taxation in Michigan, including the individual income tax. ${ }^{7}$

Section 30(1)(w) of the Michigan Income Tax Act provides for the exemption of oil and gas income from the Michigan income tax. The act specifies two adjustments Michigan taxpayers must make to their federal adjusted gross income figure concerning income from the production of oil and gas and concerning the expenses incurred to produce that oil and gas. Section 30(1)(w) provides:

For years beginning after December 31, 2011, eliminate all of the following:

(i) Income from producing oil and gas $\left[{ }^{8}\right]$ to the extent included in adjusted gross income.

(ii) Expenses of producing oil and gas to the extent deducted in arriving at adjusted gross income. ${ }^{9}$

Thus, for Michigan income tax purposes, oil and gas production income subject to the Severance Tax Act is "eliminated" by deduction from the federal adjusted gross income figure, and oil and gas

\footnotetext{
3. Мich. COMP. LAWS § 206.30(1) (2020).

4. I.R.C. § 162(a) (2012).

5. Mich. COMP. LAWS $§ 205.301$ (2020).

6. $§ 205.315$ (2020).

7. Bauer v. Dep't of Treasury, 512 N.W.2d 42, 43 (Mich. Ct. App. 1993)

8. See Mich. Comp. LAWS § 206.30(10)(a) (2020) (defining "oil and gas" as the "oil and gas subject to the severance tax under 1929 PA 48, MCL 205.301 to

9. Mich. COMP. Laws $\S 206.30(1)(w)(2020)$.
} 205.317."). 
production expenses are "eliminated" by adding the expenses back into the federal adjusted gross income figure.

In Revenue Administrative Bulletin 8 of $2018,{ }^{10}$ the Michigan Department of Treasury, which is charged with administration of the Michigan tax codes, took a broad view of the expenses that must be "eliminated" under Section 30(1)(w)(ii). Bulletin 8 directs that Michigan taxpayers must eliminate not only the direct expenses of producing oil and gas, but also the indirect and intangible expenses of producing oil and gas, including pre-production expenses and post-production expenses.

In Mannes v. Michigan Dep't of Treasury, a Michigan taxpayer challenged the Department of Treasury's broad interpretation of the expenses that must be "eliminated" under Section 30(1)(w)(ii), arguing that pre-production expenses and post-production expenses should not be eliminated, i.e., added back to taxable income. ${ }^{11}$

The court of claims framed the question as whether the phrase "'expenses of producing oil and gas' encompasses a broad set of expenses in a limited timeframe (i.e., the time of extraction) or whether it encompasses a broad set of expenses incurred at a variety of times." $" 12$ In analyzing the question, the court of claims noted that the "pertinent terms" were not defined in the Michigan Income Tax Act and turned to the dictionary to guide its interpretation. ${ }^{13}$ It chose to primarily focus its analysis on the definition of the word "of.",

The court of claims cited a range of adoptable definitions for "of," some suggesting a causality or possession requirement and others suggesting a "mere association.". Ultimately, the court selected the

10. Individual Income Tax - Eliminating The Income And Expenses Of Producing Oil And Gas, Mich. DEP'T OF TREASURY (Apr. 13, 2018), https://www.michigan.gov/documents/treasury/RAB_2018-8_-

_Oil_and_Gas_620525_7.pdf. [https://perma.cc/P8ZX - -S7V6].

11. Specifically, the taxpayer challenged Treasury's decision to "eliminate" (i.e., add back) the following expenses to taxable income: (1) amortization expense of certain geological and geophysical costs incurred prior to a well being drilled; (2) intangible drilling costs incurred before a well is capable of producing oil and gas; (3) depreciation expenses for certain wells and facilities which did not produce oil or gas during the relevant tax year; (4) the expense of a guaranteed payment by a limited liability company which was passed through to members of the company; and (5) expenses incurred for the processing, compression and transportation of natural gas after extraction from the earth. Mannes v. Mich. Dep't of Treasury, No. 18-000235-MT, 2020 WL 3891898 at*8-12 (Mich. Ct. Cl. Mar. 23, 2020).

12. Id. at $* 5$.

13. Id.

14. Id. at *5-6.

15. Id. at $* 5$. 
broad definition, requiring a "mere association." In support of its selection, the court of claims reasoned that the term "expenses" itself is broad, the statute contains no temporal limitation, and there were no cogent reasons to overrule the Department of Treasury's selection of a broad definition of the word "of" in Bulletin $8 .{ }^{16}$ Having selected a broad definition of the word "of," the court of claims concluded that $\S$ 30(1)(w)(ii) "appl[ies] to a broad set of expenses, without regard to the time when the expenses were incurred during the process of producing oil and gas." ${ }^{17}$ Accordingly, certain pre-production and post-production expenses of producing oil and gas must be added back in to the adjusted gross income when determining taxable income in Michigan.

16. Id. at $* 6-8$.

17. $I d$. at $* 8$. 